International Journal Of Mechanical Engineering And Information Technology

An Official Publication of IGM Publication

\title{
Analysis and Design of R C Chimney
}

\author{
Authors \\ Veena $\mathbf{R} \mathbf{N}^{1}$, Suresh $\mathbf{S}^{2}$ \\ ${ }^{1}$ Student, Sri Siddaganga Institute of Technology, Tumkur, India \\ ${ }^{2}$ Assistant professor, Sri Siddaganga Institute of Technology, Tumkur, India \\ Email-veenacv39@gmail.com
}

\begin{abstract}
It is essential to ensure that a structure like an $R C$ chimney shall exhibit uninterrupted performance in respect of the intended functions successfully over its expected life span. It is important to note that such expectation is made under inherent uncertainties and randomness of the basic design variables in different design situations corresponding to different limit states. An attempt is made to assess the safety of an RC chimney under different wind and earthquake conditions. The thickness may vary from a minimum of $150 \mathrm{~mm}$ at the top to the $450 \mathrm{~mm}$ at the bottom depending upon the height of the chimney. Sufficient amount of vertical steel is provided to resist the bending moment due to wind. In addition to this, horizontal steel (loop reinforcement) is provided to resist the horizontal shear and also reduce the effect of temperature gradient on concrete. The tall reinforced chimneys are wind sensitive structures and they exhibit both along wind and across wind response. So the design in this paper is governed by combined response is discussed. The design of tall RC Chimneys mainly depends on the combined values of along and across wind loads. For generating chimney model in STAAD, two types of models were considered, one with 8 node solid elements and other one with line element. Both the models were analysed and deflection was calculated.

Keywords: R C Chimney, Wind Analysis, Along and Across wind, Earth Quake Analysis, Natural frequency.
\end{abstract}

\section{BACKGROUND OF THE STUDY}

Chimneys are relatively tall structures subjected to three types of stresses. (I)Stresses due to self weight, (ii) Stresses due to wind moment and (iii) Stresses due to temperature variation between the inside and outside of the chimney. Brick chimneys are suitable only for short height as they become bulky with the increase in height and require heavy foundations also due to large temperature gradient. Brick chimney frequently cracks and become unstable. In contrast to this concrete chimneys are lighter and stronger and are less vulnerable to cracks due to the temperature difference. If the temperature of the fire gases does not exceed $400^{\circ} \mathrm{c}$, concrete chimneys can be used without any special fire brick lining. For higher temperatures, fire brick lining is provided with an air gap between the inner face of chimney and the lining. Concrete chimneys are generally constructed vertical without batter so that sliding shuttering may be used. The thickness may vary from a minimum of $150 \mathrm{~mm}$ at the top to $450 \mathrm{~mm}$ at the bottom depending upon the height of chimney. Sufficient amount of vertical steel is provided to resist the bending moment due to wind. In addition to this horizontal steel (hoop reinforcement) is provided to resist horizontal shear and also reduce the effect of temperature gradient on concrete. The loads acting on the RC circular chimneys are the self weight of the chimney, self weight of the brick lining, Wind load and the earthquake load. The self weight of the chimney and lining depends upon the shape, size and the height of the chimney. The wind load depends on the height and wind speed. The lateral load depends on the zone, type of the structure and type of the soil. Due to this moment will be caused at the base of the chimney. 


\subsection{Classification of Chimneys}

Industrial chimneys classification:

a) Based on height

i. Tall chimney

ii. Short chimney

b) Based on number of flues

i. Single flue chimney

ii. Multi flue chimney

c) Based on material of construction

i. Brick chimney

ii. Reinforced concrete chimneys

iii. Steel

iv. FRP

d) Structural support

i. Guyed chimney

ii. Self supporting

e) Lining chimney

i. Lined chimney

ii. Unlined chimney

\subsection{Literature Review}

A literature review is carried out on the design and analysis of concrete chimney with special interest. Although a number of literatures are available on the design and analysis of concrete chimney there are only aimed at providing a better understanding of the effect of interference and influence of strakes for wind loads on thermal power station chimneys and relative weakness of sections around the openings near the chimney base.

Menon and Rao(1997) reviews the code measures to estimate the across wind response of reinforced concrete chimney. In this paper, the difficulties in the codal evaluation of across wind moments and load factor provisions are examined through reliability approach. This paper mainly suggest that it is essential to design at certain conditions for the across wind loading.

K.R.C. Reddy, O.R.Jaiswal and P.N.Godbole (2011) discusses about wind and earthquake analysis of tall reinforced concrete chimney. In this paper two reinforced concrete chimneys are analysed for wind and earth quake loads. Earth quake analysis is done as per IS 1893 (part 4): 2005 and wind analysis is done as per IS 4998 (part 1): 1992. The combination of along \& across wind loads of chimney is done as per ACI 307-98 code. Finally they computed the governing load for design of chimneys.

\subsection{Importance \& Need of Study}

R C TALL Chimney is the iconic representation of power sector industry.

India, planning to add $100,000 \mathrm{MW}$ to its power map by the end of the year 2019 .

Series of failure of R C Chimney in India has caused a severe setback to the power production of the country.

In last 3 years, several tall RC Chimneys reportedly failed in India due to design and construction deficiencies.

Tall RC Chimneys need to be treated as special structures, since their behavior under loading conditions is different from any other general structures.

They are acted upon by several types of loads and with combination, of which response is both static and dynamic.

The considerations of various load combinations including the dynamic effects of wind and earthquake makes the analysis and design of RC Chimney complicated.

Each case has to be treated specifically, depending on the height of the chimney, its location, type of plant and therefore typical design are not feasible. Loads which prevail over the R C tall Chimneys are:

- Self weight -------- static

- Seismic load ------- $\quad$ static + dynamic

- Wind load --------- static + dynamic

- Temperature --------- thermal

- Circumferential ------- static

- Chemical -------- chemical action

\subsection{Objectives}

The main objective of the present study is the analysis and design of R C Chimney. The design is mainly related to the wind and earthquake effects on the chimney.

The reinforced concrete chimneys are slender, tall and generally with circular or square cross 
sections. Different construction materials are so choosen depending upon the site and weathering conditions at the site. The materials such as concrete, steel or masonry are used to build chimneys.

Design and analysis of R C Chimneys which takes into account all possible various combinations of live load + dead load + earthquake load / wind load + temperature effects in conformity with Indian standard.

Effect of various load combinations arising due to difference in seismic zone, soil condition, basic wind pressure, terrain characteristics, temperature and geometry of the chimney.

\subsection{Scope}

Industrial Chimneys are generally intended to support critical loads produced by seismic activity and wind. So it is essential to evaluate the dynamic response of chimney to seismic activity and wind loads. Response to Earthquake and wind are more critical as chimney is a slender structure. The present paper will analyse the $60 \mathrm{~m}$ reinforced concrete chimney. Comparison has been made for wind and seismic analysis. Seismic analysis is done as per IS 1893(part 4): 2005 and wind analysis as per Draft Code CED38(7892):2013 (Third revision of IS 4998(part 1):1992).Further study continues on deciding the governing loads for chimneys for the loads considered.

\subsection{Methodology}

- To achieve the above objective following step-by-step procedures are followed:

- Carry out literature study to find out the objectives of the project work.

- Understanding the design procedure of a concrete chimney as per Indian Standard IS 6533:1989.

- Analyze all the selected chimney models.

- Evaluate the analysis results.

\section{METHODOLOGY}

Meteorological Data

\begin{tabular}{|l|l|l|}
\hline S1.No. & Particulars & Values \\
\hline 1 & Elevation above mean sea level m & $50 \mathrm{~m}$ \\
\hline 2 & Ambient air temperature : & \\
& 2.1 Maximum dry bulb - Deg. C & 45.6 \\
& 2.2 Minimum dry bulb - Deg. C & 4.4 \\
\hline 3 & Relative humidity & \\
& 3.1 Maximum \% & $87 \%$ \\
& 3.2 Minimum \% & $33 \%$ \\
& 3.3 Average \% & $71 \%$ \\
\hline 4 & Annual average rainfall, mm & $1203.5 \mathrm{~mm}$ \\
\hline 5 & Basic wind speed, m/sec. & 55 \\
\hline
\end{tabular}

In this paper response of chimney was evaluated based on third revision of IS 4998 (part 1):1992.

Details of the chimney as follows,

1. Height of the chimney $-60 \mathrm{~m}$

2. Outer diameter of chimney at bottom $-5.455 \mathrm{~m}$

3 . Outer diameter of chimney at top $-3.273 \mathrm{~m}$

4. Thickness of shell at bottom $-0.15 \mathrm{~m}$

5. Thickness of shell at top $-0.15 \mathrm{~m}$

6. Thickness of air gap $-0.08 \mathrm{~m}$

7. Thickness of fire brick lining $-0.1 \mathrm{~m}$

8. Grade of concrete - M25

9. Height to base diameter ratio -11

10. Top diameter to base diameter ratio -0.6

11. Basic wind speed $-55 \mathrm{~m} / \mathrm{s}$

12. Foundation type $-\mathrm{RCC}$ circular mat

Description of loading:

Density of various materials considered for design,

Concrete $-25 \mathrm{kN} / \mathrm{m}^{3}$

Insulation $-1 \mathrm{kN} / \mathrm{m}^{3}$

Structural steel $-78.5 \mathrm{kN} / \mathrm{m}^{3}$

Live load $-5 \mathrm{kN} / \mathrm{m}^{3}$

Wind load:

The following wind parameters are followed in accessing the wind loads on the structure

Basic wind speed $-55 \mathrm{~m} / \mathrm{s}$

Terrain category -2

Class of structure $-\mathrm{c}$

Risk coefficient $\mathrm{k} 1-1$

Topography factor $\mathrm{k} 3-1$

K2 factor taken from Draft Code CED 38(7892):2013 (third revision of IS 4998(part 1):1992) 
Earthquake force data:

Earthquake load for the chimney has been calculated as per IS 1893(par 4): 2005

Zone factor -0.16

Seismic zone - III

Importance factor $(\mathrm{I})-1.5$

Reduction factor $(\mathrm{R})-3$

\section{STAAD MODEL}

For generating chimney model in STAAD, two types of models were considered, one with 8 node solid elements and other one with line element. Both the models were analysed and deflection was calculated. It is found that the deflection value for the 8 node solid element model and the linear model are same, so for making the model generation easy linear element was chosen. Mode shapes and frequencies are calculated using STAAD. A factor of 1.2 was multiplied to take in to account of accessories of chimney to its selfweight.

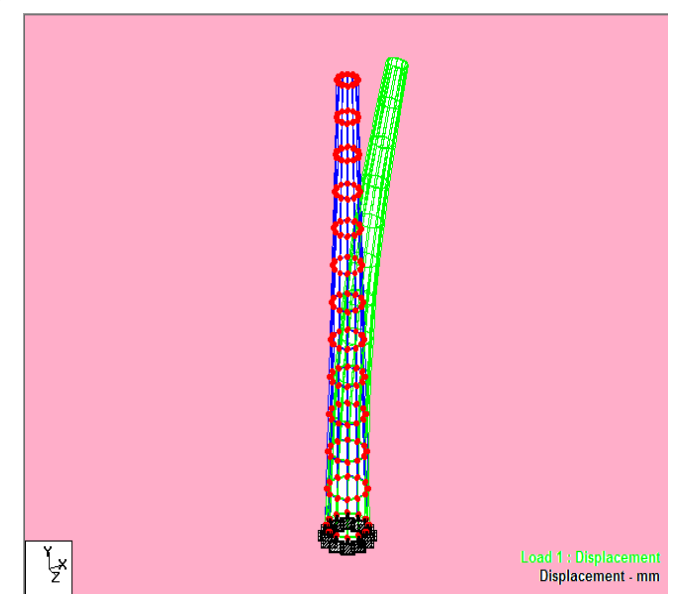

Fig.3.1 STAAD model of chimney using 8 node solid elements

In the above figure 3.1 STAAD model of chimney using 8 node solid elements, shows $60 \mathrm{~m}$ chimney having fixed supports assigned to base elements and the topmost elements are left free to ensure cantilever action. Under the calculated horizontal forces the displacement of this chimney was noted to compare it with chimney model generated using linear/ beam element.

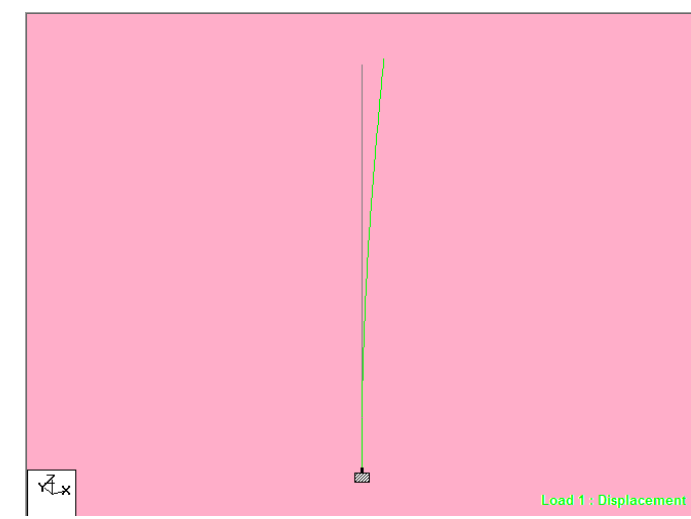

Fig.3.2 STAAD model of chimney using Line/Beam elements

In the above figure 3.2 STAAD model of chimney using Line/Beam elements, shows $60 \mathrm{~m}$ chimney having fixed support assigned to base node of the bottom most element. Cross sections were assigned using tapered tube element. For the same horizontal load mentioned above this model was analysed for deflection. It is found that both the deflection values are same. Hence, for modal analysis linear element model was adopted for easier evaluation and interpretation of results.

\subsection{Estimation of Wind Loads}

In tall structures like industrial chimneys, wind forces usually govern the design. Wind effect can be divided into two components. Those are along wind and across wind effects. Due to drag force on chimney, along wind loads occur. Due to lift force on chimney, across wind loads occur. When wind forces acts on the structure, buffeting effect is produced because of along wind loads. For the reason of evaluation of loads, the chimney is designed as a cantilever whose bases fixed to the ground. Generally wind does not blow at fixed rate. It blows at gusts. So this requires that the effects are taken in terms of equivalent loads. Here chimney is analysed as a bluff body having turbulent flow for the computation of along wind loads. Equivalent static procedure is used in codes known as gust factor method. Currently stipulated in all building codes and also in Draft Code CED 38(7892):2013 (third revision of IS 4998(part 1):1992).

In this method wind pressure which is assumed to be acting on face of the chimney, due to this wind 
pressures are considered as static wind loads. This is then improved using the gust factor to make sure of the dynamic effects. The following codes used in estimation of along wing loads are:

$\square$ IS875 (part 3):1987 - code practice for design loads for building and structures [8].

$\square$ Draft Code CED 38(7892):2013 (third revision of IS 4998(part 1):1992)

3.2 Estimation of Earthquake Loads

For the calculation of earthquake loads, there are two methods available in Indian standards. These two methods are used to evaluate the design forces. Earth quake analysis was carried out by using 1893 (part 4): 2005 [9]

Moment and Shear Force Calculation:

For evaluation of moment and shear force, the following are required.

1) The fundamental time period of the free vibration is,

$T=C_{T} \sqrt{ }(W t / E s A g)$

Where

$\mathrm{CT}=$ Coefficient depending on slenderness ratio of the structure

$\mathrm{W} \mathrm{t}=$ Total weight of the structure including lining weight,

$\mathrm{A}=$ Area of cross-section at the base of the structural shell

$\mathrm{h}=$ Total height of the structure

Es $=$ Modulus of elasticity of material of the structural shell

$\mathrm{g}=$ Acceleration due to gravity

\section{EXPERIMENTAL RESULTS}

Table 4.1: Free vibration characteristics of chimney

\begin{tabular}{|l|l|l|l|l|l|l|}
\hline \multirow{2}{*}{$\begin{array}{l}\text { Chimney } \\
\text { height } \\
(\mathrm{m})\end{array}$} & \multicolumn{3}{|l|}{ Base shear(kN) } & \multicolumn{2}{l|}{ Base moment (kN-m) } \\
\cline { 2 - 7 } & $\begin{array}{l}\text { Along } \\
\text { wind }\end{array}$ & $\begin{array}{l}\text { Across } \\
\text { wind }\end{array}$ & $\begin{array}{l}\text { Combine } \\
\text { d wind }\end{array}$ & $\begin{array}{l}\text { Along } \\
\text { wind }\end{array}$ & $\begin{array}{l}\text { Across } \\
\text { wind }\end{array}$ & $\begin{array}{l}\text { Combin } \\
\text { ed wind }\end{array}$ \\
\hline 60 & 19.26 & 158.42 & 159.65 & 585.00 & 7237.79 & 7261.38 \\
\hline
\end{tabular}

Table 4.1 represents Natural frequencies and corresponding time periods for the $60 \mathrm{~m}$ chimney. These results correspond to modal analysis of linear model generated in STAAD as discussed above. The mode shapes for each frequency obtained were used in the wind analysis as per Draft Code CED 38(7892):2013 (third revision of IS 4998(part 1):1992).

Table 4.2: Results of earthquake analysis

\begin{tabular}{|l|l|l|l|l|}
\hline S.No & Zone & $\begin{array}{l}\text { Zone } \\
\text { factor }\end{array}$ & $\begin{array}{l}\text { Shear } \\
\text { force(kN) }\end{array}$ & $\begin{array}{l}\text { Bending } \\
\text { moment(kN-m) }\end{array}$ \\
\hline 1 & II & 0.10 & 148.47 & 2989.38 \\
\hline 2 & III & 0.16 & 238.09 & 4739.74 \\
\hline 3 & IV & 0.24 & 357.14 & 7190.61 \\
\hline
\end{tabular}

Table 4.2 represents the results of earthquake analysis about the Shear force and Bending Moment values for the zones II, III \& IV. Analysis is carried out using IS 1893 (part4): 2005. It is observed that there is at least $50 \%$ increase in moments in every zone when compared to its previous zone. These are the maximum moments obtained at the base of the chimney.

\section{Table 4.3: Results of wind analysis}

Table 4.3 represents the results of wind analysis that is Shear force and Bending Moment values obtained from the wind analysis for the wind speed of $55 \mathrm{~m} / \mathrm{s}$ as per Draft Code CED 38(7892):2013 (third revision of IS 4998(part 1):1992)for a $60 \mathrm{~m}$ chimney height. The wind analysis consists of calculating along and across wind effects separately and combined effect is computed and presented. It is observed that the across wind effects are quite significant when compared to along wind effects. Also the combined wind base shear and also the base moments values are more similar to the across wind effect values.

\begin{tabular}{|c|l|l|l|l|}
\hline $\begin{array}{c}\text { Chimney } \\
\text { height } \\
(\mathrm{m})\end{array}$ & \multicolumn{2}{|l|}{$\begin{array}{l}\text { Natural } \\
\text { frequency }(\mathrm{Hz})\end{array}$} & \multicolumn{2}{l|}{ Time period(sec) } \\
\cline { 2 - 5 } & $\begin{array}{l}\text { 1st } \\
\text { mode }\end{array}$ & $\begin{array}{l}\text { 2nd } \\
\text { mode }\end{array}$ & $\begin{array}{l}\text { 1st } \\
\text { mode }\end{array}$ & $\begin{array}{l}\text { 2nd } \\
\text { mode }\end{array}$ \\
\hline 60 & 0.8 & 4.147 & 1.208 & 0.241 \\
\hline
\end{tabular}

\section{CONCLUSIONS}

On studying the results presented in the above tables, it shows that as the zone factor increases the values of shear force and bending moment increases. 
The effect of wind force for $55 \mathrm{~m} / \mathrm{s}$ wind speed is quite significant as compared with the earth quake forces in Zone II and Zone III.

Moment due to earthquake in Zone III is almost equal to the Combined Moment due to wind speed of $55 \mathrm{~m} / \mathrm{s}$.

As per draft code the deflection at the free end of the chimney should be well within the permissible limits.

For 60m RCC Chimney of chosen geometric proportions, wind forces governing the design.

\section{REFERENCES:}

1. Shaikh M. G and Khan A.M.I., "Governing Loads for Design of a tall RCC Chimney", IOSR Journal of Mechanical and Civil Engineering, 12-19

2. Siva K. R., Rohini P.V and Srikanth C.( 2012),"Study of Wind Load Effects on Tall RC Chimneys", International Journal of Advanced Engineering Technology, 3:9297

3. Dhahri A and Ahmed.(2013), “A Review of solar Chimney Power Generation Technology", International Journal of Engineering and Advanced Technology, 2:2249-8958

4. Rajkumar. and Vishwanath. B. (2013), "Analysis of Self-Supporting Chimney", International Journal of Innovative Technology and Exploring Engineering, 3: 2278-3075

5. Manoj K., Bajpai V.K. and Garg T.K. (2009), "Design of Vibration-Dampers For Steel Chimneys with Latest Features", International Journal on Design and Manufacturing Technologies, 3: 39-42

6. Reddy K. R. C. , Jaiswal O. R. and Godbole P. N. (2011),“ Wind and Earthquake Analysis of Tall RC
Chimneys", International Journal of Earth Sciences and Engineering, 4: 508-511

7. Murali G., Mohan B., Sitara P and Jayasree P. (2012), "Response of Mild Steel chimney Under Wind Loads", International Journal of Engineering Research and Applications, 2:490-498

8. Pradeep A. and Siva R.P. (2014), "Governing Loads For Design of a $60 \mathrm{~m}$ Industrial RCC Chimney", International Journal of Innovative Research in Science,Engineering and Technology, 3: 2319-8753

9. Yoganantham.C. and Santhi.H. (2013), "Modal Analysis of R.C.C Chimney", International Journal of Research in Civil Engineering Architecture \& Design”, 1:20-23

10. Jayalekshmi B. R.,. Jisha S. V, and Shivashankar R. (2013), "Soil-Structure Interaction Analysis of Tall Reinforced Concrete Chimney with Piled Raft and Annular Raft under Along-Wind Load", Journal of Structures.

11. Takmil S., Baizid K. P and Shamim A.(2014), "Design,Construction and Performance Test of a Small Solar Chimney Power Plant",Global Journal of Researches in Engineering",14: 20-28

12. John L.W. (2002), "Aseismic Design of Tall Reinforced Concrete Chimneys", Structural Journal“, 99: 622-630 